\title{
FOOD CONSUMPTION OF CIRRHOTIC PATIENTS, COMPARISON WITH THE NUTRITIONAL STATUS AND DISEASE STAGING
}

\author{
Flavia Feijó NUNES, Lílian BASSANI, Sabrina Alves FERNANDES, \\ Maria Eugênia DEUTRICH, Bianca Coccaro PIVATTO and Cláudio Augusto MARRONI
}

Received 15/2/2016

Accepted 1/6/2016

\begin{abstract}
Background - Patients with liver disease often present protein-energy malnutrition. The assessment of food intake is very important in the investigation regarding the "health-disease" process. Objective - To assess dietary intake of cirrhotic patients through food record during 3 days, correlating it with the nutritional status of the patient and the stage of the disease. Methods - Cirrhotic outpatients from the Santa Casa de Misericórdia Hospital, RS, Brazil, were assessed. Nutritional assessment was performed by anthropometry; non-dominating handgrip strength; adductor pollicis muscle thickness; phase angle by bioelectrical impedance analysis; and Subjective Global Assessment. For analysis of food consumption we used the food records of 3 days using scales for weighing of all foods. Results - We evaluated $25(68 \%)$ patients, in which there was a prevalence of cirrhosis by hepatitis $\mathrm{C}$ virus. The upper arm circumference, handgrip strength and phase angle by bioelectrical impedance analysis diagnosed $56 \%$ of malnourished. Phase angle by bioelectrical impedance analysis and upper arm circumference were associated with Child-Pugh score $(P<0.05)$. The average consumption of calories, carbohydrates, proteins and lipids were within the recommended. However, sodium was above the recommendations, $106 \pm 57.2 \mathrm{mEq}$, and was inversely associated with Child-Pugh score $(\mathrm{rs}=-0.410 ; P=0.042)$. Conclusion - Food intake did not have a significant difference between the Child-Pugh scores and nutritional status. In addition, food intake did not vary neither according to the stage of the disease, nor to the nutritional assessment, by the phase angle by bioelectrical impedance analysis.
\end{abstract}

HEADINGS - Liver cirrhosis. Food consumption. Nutrition assessment.

\section{INTRODUCTION}

Protein-energy malnutrition (PEM) is highly prevalent in patients with liver disease and leads to serious repercussions on the general state, having a direct impact on cirrhotic patient prognosis, deteriorating liver function, adversely affecting the clinical evolution $^{(22)}$ and reflecting on the morbidity and mortality of these ills ${ }^{(1)}$. The prevalence of malnutrition in decompensated cirrhosis ranges from $60 \%-100 \%$, while $20 \%-30 \%$ of patients with compensated cirrhosis are also malnourished ${ }^{(24,30)}$. In ambulatory cirrhotic patients, PEM occurs in $75 \%$, and the highest malnutrition covers the patients Child B and C category ${ }^{(9)}$.

Nutritional assessment is crucial in the investigation of alterations associated with liver disease, since it is through it that the conduct of correction or maintenance of the nutritional status of patients will be built upon ${ }^{(12,18)}$. However, so far, there is not a method considered "gold standard", able to accurately diagnose changes in the nutritional status of these patients.
Nowadays, the employed nutritional assessment methods are anthropometric measures, which include weight, height, calculation of body mass index (BMI), skinfolds (triceps skinfold (TSF)) and circumference of the limbs (upper arm circumference (UAC), arm muscle circumference (AMC); muscle strength (HGS) - measured by dynamometry; adductor pollicis muscle thickness (APMT); bioelectrical impedance analysis; clinical nutritional assessment, conducted through the Subjective Global Assessment (SGA); and biochemical methods (such as prealbumin, albumin, transferrin, lymphocyte count and total blood count).

Assessment of food intake is essential in the investigation of the relationship "health-disease" process, in the formulation of preventing methods of certain diseases, in the adequate supply of food and monitoring the food consumption ${ }^{(12)}$. When we wish to quantify and evaluate nutrient intake, the most appropriate instruments are able to collect detailed information on food consumption, regarding the food and quantities ingested. To this end, the most commonly used methods are: the 24-hour recall (R24h) and the food record ${ }^{(15)}$. 
The food record is an evaluation method for food consumption, which collects information about the current intake of an individual or population group. This method can be applied in two ways: first, the individual or responsible must register the portion size in household measures; second, all the food consumed must be weighed and recorded, and if there are leftovers, it also must be weighed and recorded. The last manner of application is used, in general, in studies in which it is necessary to accurately estimate the nutrients. Typically, the method can be applied for 3,5 or 7 days longer than seven days can compromise adhesion and data reliability ${ }^{(12)}$. The three days' record has the advantage of being faster and less tiring for the individual.

The food record, as a method of consumption evaluation, presents advantages such as: ease of carrying out the record at home; does not require the memory of the patient; the skipping meals tends to be minimal in this survey, but the patient must be well instructed on how to register the food and to preferably register it right after its intake. The food record that includes the use of scale can be considered a very accurate method, but it requires effort and will of collaboration ${ }^{(12)}$.

The aim of this study is to evaluate food intake of cirrhotic patients through the three days' food record, correlating it with the nutritional status of the patient and the stage of the disease.

\section{METHODS}

This present work is characterized as a cross-sectional study. The study enrolled adults patients diagnosed with cirrhosis by different etiologies in clinical treatment in the Gastroenterology Clinic of the Santa Clara Hospital of the Irmandade Santa Casa de Misericórdia de Porto Alegre, Rio Grande do Sul, Brazil. The severity of liver disease was assessed by the Child-Pugh classification, score used as predictor of the severity of the disease, which is based on five criteria that would indicate changes in liver function, as follows: serum bilirubin, serum albumin, ascites, neurologic disorder, and prothrombin time. All participants agreed to participate in the study by signing the free and informed consent form, after guidance as to the nature and aim of the study. The research project was approved by the Research Ethics Committee of the Universidade Federal de Ciências da Saúde de Porto Alegre (UFCSPA), under protocol number 708-08. Data collection took place from March 2010 to March 2012.

Patients using enteral nutrition, carriers of neurological disorders or other medical conditions that would prevent understanding for food records and answers' provision or anthropometric measurements, were excluded from the study. Also, patients with neuromuscular disorders in the upper limbs; chronic renal failure, chronic pancreatitis, chronic diarrhea, inflammatory bowel disease, symptomatic HIV +, and cancer patients with advanced stage were also excluded, since these diseases affect metabolism and nutrients absorption.

Patients were interviewed on the same day of outpatient clinical care. To the patients selected for the study, consecutively, it was given a domestic trade balance with scale 1-125g (Plenna $\left.{ }^{\circledR}\right)$ for weighing food, and asked to weigh and write down all intake food in two days of the week and one day of the weekend. Nutritional assessment by different methods was carried out at the time the patient returned to the clinic with the records.

The detailed dietary survey was based on the information recall 3 days of the patient's week, in which all the food and ingested quantities were recorded. At the first visit, protocol was filled up and instructions for handling the domestic balance, needed to weigh and measure foods consumed during the day, were given. Patients were instructed not to modify the location and eating habits. At home, the patients recorded (on a provided printed sheet) the weight and household measure of the eaten food during 3 days, being two of them weekdays and one of them a day of the weekend (Saturday or Sunday). It was also provided to the patient a plate and plastic cup to measure the food, or, if they do not accept using the supplied glass plate, they were told to discount the weight of the used utensil. Later, after they returned with the records, about 1 month after initiating, the researcher performed the analysis of the food consumed in 3 days, resulting in the average record of calories, macronutrients (carbohydrates, proteins and lipids) and micronutrients (zinc, iron, sodium, potassium, calcium) that were normally ingested.

Dietary intake of macronutrients and micronutrients was calculated by Nutwin software, version 1.5 of the Department of Health Informatics of the Universidade Federal de São Paulo ${ }^{(3)}$. Nutrients were classified as to the adequacy of consumption below the recommended, recommended and above the recommended, as recommendations for calories and proteins ${ }^{(6)}$; carbohydrates, lipids and sodium ${ }^{(29)}$; zinc, iron, potassium and calcium ${ }^{(28)}$.

Assessment of nutritional status was performed by applying diagnostic procedures in sequence (anthropometry, HGS, APMT, electrical bioimpedance and SGA). The classic anthropometry was performed using the weight, height, triceps skinfold, upper arm circumference, arm muscle circumference and body mass index, the last two being obtained by mathematical formulas. For anthropometry, we used the stadiometer fixed to the wall, scale with $100 \mathrm{~g}$ of scale (Filizola ${ }^{\circledR}$ ), scientific skinfold caliper $\left(\mathrm{Cescorf}^{\mathbb{B}}\right)$ and inelastic tape. The calculation of BMI (weight divided by height squared) enabled the classification of the nutritional status, according to the recommendation of the World Health Organization ${ }^{(36)}$. The results obtained for the remaining indicators were related to the default values shown in percentiles tables of Frisancho ${ }^{(16)}$ and classified according to Blackburn \& Thornton ${ }^{(7)}$.

The measurement of non-dominating handgrip strength was performed by dynamometry ${ }^{(12)}$, for which it was used a mechanical dynamometer of Baseline ${ }^{\circledR}$, Smedley Spring model. The results were classified as Alvarez-da-Silva \& Silveira ${ }^{(2)}$. For the adductor pollicis muscle thickness measurement, it was used scientific plicometer of Cescorf ${ }^{\circledR}$. The results were classified as Lameu et al. ${ }^{(25)}$.

The phase angle (PA) assessed to classify the nutritional status was obtained by bioelectrical impedance, Biodynamics, model 450, Seattle, WA, USA. The patient remained in dorsal decubitus position, both hands and legs parallel to the body. We placed one electrode on the dorsal hand, at the middle finger level, and another one in the wrist joint, always on the 
right side. The electrical current used in the measurement was $800 \mathrm{~A}$ and $50 \mathrm{kHz}$. This enabled to measure resistance and reactance, and also obtain the phase angle (PA) value. The PA derives from two segments of corporal composition, and is calculated from the formula: $\mathrm{PA}=$ tangent $\operatorname{arc}(\mathrm{Xc} / \mathrm{R})$ x 180/3.1416, proposed by Barbosa-Silva et al. ${ }^{(5)}$. The result enables the classification of the patient according to his/her nutritional state. They were classified based on the cutoff points that were established according to age and gender, based on a study of the Brazilian population ${ }^{(4)}$.

After the anthropometric measurements, Subjective Global Assessment validated by Detsky et al. was carried out $^{(11)}$. Patients were asked about the changes on the usual weight in the last 6 months; changes on eating habits; presence of gastrointestinal symptoms and signs (nausea, vomiting, diarrhea, constipation) and disorders of functional capacity. It was performed a physical examination aiming to identify changes in subcutaneous composition: fat loss, muscle mass and presence of extravascular fluid.

Statistical analyzes of the data were performed using SPSS (Statistical Package for the Social Sciences) 17.0 version, whereas the level of significance was $5 \%(P \leq 0.05)$. The quantitative variables were expressed as mean and standard deviation, and qualitative variables by absolute and relative frequencies. To compare means in two groups, the Student $t$ test was used. For more than two groups, analysis of variance (ANOVA) with oneway post-hoc Tukey test was applied. In the association between categorical variables, the chi-square test of Pearson was applied. To compare the nutritional assessment methods, McNemar test was used. When comparing the food intake as the day of the week, the analysis of variance (ANOVA) for repeated measures was used. The association between the severity of the disease with the consumption of macronutrients and micronutrients was assessed using Spearman's correlation coefficient.

\section{RESULTS}

The casuist consisted of 25 cirrhotic patients adults with a mean age of $55.8 \pm 10.8$ years, being $14(56 \%)$ male individuals. The most prevalent etiologies of cirrhosis were the hepatitis C virus (68\%) and alcohol (24\%). As for the severity of the disease, the majority of patients, $12(48 \%)$, were Child Pugh A and 9 (36\%) were Child Pugh B, being only $4(16 \%)$ Child Pugh C. According to the nutritional assessment methods used, BMI, APMT and SGA did not diagnose any patient as malnourished, whereas APMT and SGA diagnosed all patients as well nourished. The UAC, HGS and bioelectrical impedance analysis (BIA) through the PA were the methods that most diagnosed malnourished, they all diagnosed $14(56 \%)$ patients. There was a significant difference between the methods of nutritional assessment. Anthropometric characteristics are described in Table 1.

When we associate the different nutritional assessment methods with Child-Pugh score, the PA by bioelectrical impedance and upper arm circumference were the methods that had statistically significant association to the disease stage $(P<0.05)$ (Table 2$)$.
TABLE 1 . Nutritional assessment of cirrhotic patients by different methods

\begin{tabular}{lcccc}
\hline & & \multicolumn{3}{c}{ Nutritional status } \\
\cline { 3 - 5 } Methods & $\begin{array}{c}\text { Mean } \pm \\
\text { SD }\end{array}$ & $\begin{array}{c}\text { Malnourished } \\
\mathbf{n}(\%)\end{array}$ & $\begin{array}{c}\text { Well } \\
\text { nourished } \\
\mathbf{n}(\%)\end{array}$ & $\begin{array}{c}\text { Overweight } \\
\mathbf{n}(\%)\end{array}$ \\
\hline BMI $\left(\mathrm{kg} / \mathrm{m}^{2}\right)$ & $29.2 \pm 7.1$ & $0(0.0)^{\mathrm{a}}$ & $9(36.0)$ & $16(64.0)$ \\
$\mathrm{UAC}(\mathrm{cm})$ & $30.2 \pm 5.1$ & $14(56.0)^{\mathrm{b}}$ & $8(32.0)$ & $3(12.0)$ \\
TSF $(\mathrm{mm})$ & $18.3 \pm 9.8$ & $10(40.0)^{\mathrm{b}}$ & $5(20.0)$ & $10(40.0)$ \\
AMC $(\mathrm{cm})$ & $24.3 \pm 3.8$ & $11(44.0)^{\mathrm{b}}$ & $14(56.0)$ & - \\
HGS $(\mathrm{kg} / \mathrm{f})$ & $28.4 \pm$ & $14(56.0)^{\mathrm{b}}$ & $11(44.0)$ & - \\
APMT $(\mathrm{mm})$ & 19.7 & $0(0.0)^{\mathrm{a}}$ & $25(100)$ & - \\
BIA $\left(^{\circ}\right)$ & $6.3 \pm 2.1$ & $14(56.0)^{\mathrm{b}}$ & $11(44.0)$ & - \\
SGA & - & $0(0.0)^{\mathrm{a}}$ & $25(100)$ & - \\
\hline
\end{tabular}

a,b Same letters do not differ by the McNemar test. BMI: body mass index; UAC: upper arm cicrunference; TSF: triceps skinfold; AMC: arm muscle circumference; HGS: non-dominating handgrip strength; APMT: adductor pollicis muscle thickness; BIA: bioelectrical impedance phase angle; SGA: subjective global assessment.

TABLE 2. Association of nutritional status with Child-Pugh score

\begin{tabular}{|c|c|c|c|c|}
\hline Methods & $\begin{array}{c}\text { Child A } \\
12(48 \%)\end{array}$ & $\begin{array}{l}\text { Child B } \\
9(36 \%)\end{array}$ & $\begin{array}{l}\text { Child C } \\
4(16 \%)\end{array}$ & $P^{*}$ \\
\hline BMI $\left(\mathrm{kg} / \mathrm{m}^{2}\right)$ & & & & - \\
\hline Malnourished - n (\%) & $0(0.0)$ & $0(0.0)$ & $0(0.0)$ & \\
\hline Well nourished - $\mathrm{n}(\%)$ & $12(100)$ & $9(100)$ & $4(100)$ & \\
\hline $\mathrm{UAC}(\mathrm{cm})$ & & & & 0.008 \\
\hline Malnourished - n (\%) & $3(25.0)$ & $7(77.8)$ & $4(100)$ & \\
\hline Well nourished - $\mathrm{n}(\%)$ & $9(75.0)$ & $2(22.2)$ & $0(0.0)$ & \\
\hline $\mathrm{TSF}(\mathrm{mm})$ & & & & 0.198 \\
\hline Malnourished - n (\%) & $3(25.0)$ & $4(44.4)$ & $3(75.0)$ & \\
\hline Well nourished - $\mathrm{n}(\%)$ & $9(75.0)$ & $5(55.6)$ & $1(25.0)$ & \\
\hline $\operatorname{AMC}(\mathrm{cm})$ & & & & 0.347 \\
\hline Malnourished - n (\%) & $4(33.3)$ & $4(44.4)$ & $3(75.0)$ & \\
\hline Well nourished - $\mathrm{n}(\%)$ & $8(66.7)$ & $5(55.6)$ & $1(25.0)$ & \\
\hline HGS $(\mathrm{kg} / \mathrm{f})$ & & & & 0.577 \\
\hline Malnourished - n (\%) & $8(66.7)$ & $4(44.4)$ & $2(50.0)$ & \\
\hline Well nourished - $\mathrm{n}(\%)$ & $4(33.3)$ & $5(55.6)$ & $2(50.0)$ & \\
\hline $\operatorname{APMT}(\mathrm{mm})$ & & & & - \\
\hline Malnourished - n (\%) & $0(0.0)$ & $0(0.0)$ & $0(0.0)$ & \\
\hline Well nourished - $\mathrm{n}(\%)$ & $12(100)$ & $9(36.0)$ & $4(16.0)$ & \\
\hline $\mathrm{BIA}\left({ }^{\circ}\right)$ & & & & 0.001 \\
\hline Malnourished - n (\%) & $2(16.7)$ & $8(88.9)$ & $4(100)$ & \\
\hline Well nourished - n (\%) & $10(83.3)$ & $1(11.1)$ & $0(0.0)$ & \\
\hline SGA & & & & - \\
\hline Malnourished - n (\%) & $0(0.0)$ & $0(0.0)$ & $0(0.0)$ & \\
\hline Well nourished - n (\%) & $12(100)$ & $9(36.0)$ & $4(16.0)$ & \\
\hline
\end{tabular}

From the three-day food record, we analyzed the food consumption of calories, macronutrients (carbohydrates, proteins and lipids) and micronutrients (zinc, iron, sodium, potassium and calcium). The average number of calories consumed was $26.4 \pm 8.3 \mathrm{Kcal} / \mathrm{kg}$, and most of the patients studied, $12(48 \%)$, had a consumption below the recommended. 
The same happened to the proteins, of which $15(60 \%)$ of the patients also had a consumption below the recommended. The carbohydrate intake was in line with the recommendations for most patients, $13(52 \%)$, and they all had a consumption of lipids within the recommended. As for the micronutrients intake, zinc remained within the recommendations in $16(64.2 \%)$ patients. The iron intake was within the recommended in $100 \%$ of individuals and, on the other hand, potassium was below the recommended in $100 \%$ of the individuals. Sodium was consumed above the recommended amounts in $18(72 \%)$ patients, and as for the calcium, almost all individuals, $24(96 \%)$ showed a consumption below recommended.

The consumption of none of macronutrients and micronutrients differed significantly according to the Child-Pugh classification A, B, or C, so it didn't significantly varied according to the severity of liver disease. However, we could observe that the Child-Pugh C patients had a lower intake of total calories, protein and micronutrients analyzed. These results are shown in Table 3.
Associating the average intake of total calories, macronutrients and micronutrients from the three-day food record with the Child-Pugh score by Spearman coefficient, we observed that only sodium had association with the Child ( $\mathrm{rs}=-0.410 ; P=0.042)$, and this association was inverse. Therefore, the higher the score of disease's severity, the lower the consumption of sodium.

Calories, macronutrients and micronutrients intake, when compared to the patient's nutitional status, showed no statistical difference between well nourished and malnourished. When comparing the dietary intake and nutritional status through the PA by BIA, we found that malnourished patients consume fewer calories than well nourished, but without significantly statistical difference. In both nutritional status, caloric intake was below the recommended in most of the patients (Table 4). In the analysis of the carbohydrates consumption, lipids and proteins, related to the patient's nutritional status through the phase angle by BIA, showed that malnourished patients had a consumption slightly larger than the well-nourished. The carbohydrate intake was within the recommended levels

TABLE 3. Calorie food intake of macronutrients and micronutrients as Child-Pugh score

\begin{tabular}{|c|c|c|c|c|c|}
\hline \multirow[b]{2}{*}{ Food consumption } & \multirow[b]{2}{*}{$\begin{array}{c}\text { Total sample } \\
25(100 \%)\end{array}$} & \multicolumn{4}{|c|}{ Child-Pugh } \\
\hline & & $\begin{array}{c}\mathrm{A} \\
12(48 \%)\end{array}$ & $\begin{array}{c}\text { B } \\
9(36 \%)\end{array}$ & $\begin{array}{c}C \\
4(16 \%)\end{array}$ & $P$ \\
\hline VET (kcal) & $2012 \pm 720$ & $1997 \pm 892$ & $2169 \pm 480$ & $1702 \pm 641$ & $0.576^{*}$ \\
\hline $\operatorname{VET}(\mathrm{kcal} / \mathrm{kg})$ & $26.4 \pm 8.3$ & $25.1 \pm 7.9$ & $28.6 \pm 9.6$ & $25.3 \pm 7.4$ & $0.635 *$ \\
\hline Below the recommended - $\mathrm{n}(\%)$ & $12(48.0)$ & $7(58.3)$ & $3(33.3)$ & $2(50.0)$ & \\
\hline Recommended - n (\%) & $4(16.0)$ & $1(8.3)$ & $2(22.2)$ & $1(25.0)$ & \\
\hline Above recommended - $\mathrm{n}(\%)$ & $9(36.0)$ & $4(33.3)$ & $4(44.4)$ & $1(25.0)$ & \\
\hline $\mathrm{CHO}(\mathrm{g})$ & $286 \pm 113$ & $272 \pm 139$ & $322 \pm 67.5$ & $243 \pm 111.5$ & $0.455^{*}$ \\
\hline $\mathrm{CHO}(\%)$ & $56.4 \pm 7.1$ & $53.5 \pm 7.0$ & $60.1 \pm 5.1$ & $56.6 \pm 7.1$ & $0.085 *$ \\
\hline Below the recommended - $\mathrm{n}(\%)$ & $4(16.0)$ & $3(25.0)$ & $1(11.1)$ & $0(0.0)$ & \\
\hline Recommended - n (\%) & $13(52.0)$ & $6(50.0)$ & $4(44.4)$ & $3(75.0)$ & \\
\hline Above recommended - $\mathrm{n}(\%)$ & $8(32, .0)$ & $3(25.0)$ & $4(44.4)$ & $1(25.0)$ & \\
\hline PTN $(\mathrm{g})$ & $79.6 \pm 26.7$ & $80.9 \pm 27.8$ & $84.4 \pm 26.1$ & $65.0 \pm 26.4$ & $0.485 *$ \\
\hline PTN $(g / k g)$ & $1.05 \pm 0.35$ & $1.03 \pm 0.31$ & $1,10 \pm 0,40$ & $0.98 \pm 0.40$ & $0.822 *$ \\
\hline Below the recommended - $\mathrm{n}(\%)$ & $15(60.0)$ & $8(66.7)$ & $4(44.4)$ & $3(75.0)$ & \\
\hline Recommended - n (\%) & $2(8.0)$ & $0(0.0)$ & $2(22.2)$ & $0(0.0)$ & \\
\hline Above recommended - $\mathrm{n}(\%)$ & $8(32.0)$ & $4(33.3)$ & $3(33.3)$ & $1(25.0)$ & \\
\hline $\operatorname{LIP}(g)$ & $65.0 \pm 25.3$ & $66.6 \pm 30.9$ & $67.1 \pm 20.4$ & $55.6 \pm 19.6$ & $0.735 *$ \\
\hline $\operatorname{LIP}(\%)$ & $29.3 \pm 4.4$ & $30.1 \pm 4.8$ & $27.7 \pm 4.4$ & $30.0 \pm 2.9$ & $0.444 *$ \\
\hline Below the recommended $-\mathrm{n}(\%)$ & $0(0.0)$ & $0(0.0)$ & $0(0.0)$ & $0(0.0)$ & \\
\hline Recommended - n (\%) & $25(100)$ & $12(100)$ & $9(100)$ & $4(100)$ & \\
\hline Zinc (mg) & $9.1 \pm 3.1$ & $9.0 \pm 2.9$ & $9.9 \pm 3.9$ & $7.6 \pm 1.9$ & $0.499 *$ \\
\hline Below the recommended - $\mathrm{n}(\%)$ & $9(36.0)$ & $3(25.0)$ & $3(33.3)$ & $3(75.0)$ & \\
\hline Recommended - n (\%) & $16(64.0)$ & $9(75.0)$ & $6(66.7)$ & $1(25.0)$ & \\
\hline Iron $(\mathrm{mg})$ & $14.6 \pm 6.5$ & $14.5 \pm 9.0$ & $15.8 \pm 2.7$ & $12.1 \pm 3.2$ & $0.665 *$ \\
\hline Below the recommended - $\mathrm{n}(\%)$ & $0(0.0)$ & $0(0.0)$ & $0(0.0)$ & $0(0.0)$ & \\
\hline Recommended - n (\%) & $25(100)$ & $12(100)$ & $9(100)$ & $4(100)$ & \\
\hline Sodium (mEq) & $106 \pm 57.2$ & $121 \pm 55.3$ & $109 \pm 60.3$ & $51.6 \pm 18.1$ & $0.098 *$ \\
\hline Below the recommended - $\mathrm{n}(\%)$ & $4(16.0)$ & $2(16.7)$ & $1(11.1)$ & $1(25.0)$ & \\
\hline Recommended - n (\%) & $3(12.0)$ & $0(0.0)$ & $1(11.1)$ & $2(50.0)$ & \\
\hline Above recommended - $\mathrm{n}(\%)$ & $18(72.0)$ & $10(83.3)$ & $7(77.8)$ & $1(25.0)$ & \\
\hline Potassium (mg) & $1935 \pm 785$ & $1908 \pm 856$ & $2142 \pm 775$ & $1552 \pm 565$ & $0.471 *$ \\
\hline Below the recommended $-\mathrm{n}(\%)$ & $25(100)$ & $12(100)$ & $9(100)$ & $4(100)$ & \\
\hline Recommended - n (\%) & $0(0.0)$ & $0(0.0)$ & $0(0.0)$ & $0(0.0)$ & \\
\hline Calcium(mg) & $607 \pm 263$ & $651 \pm 325$ & $629 \pm 151$ & $425 \pm 226$ & $0.331 *$ \\
\hline Below the recommended - $\mathrm{n}(\%)$ & $24(96.0)$ & $11(91.7)$ & $9(100)$ & $4(100)$ & \\
\hline Recommended - n (\%) & $1(4.0)$ & $1(8.3)$ & $0(0.0)$ & $0(0.0)$ & \\
\hline
\end{tabular}


TABLE 4. Calorie food intake of macronutrients and micronutrients as nutritional status according to the phase angle by BIA

\begin{tabular}{|c|c|c|c|}
\hline \multirow[b]{2}{*}{ Food consumption } & \multicolumn{2}{|c|}{ Nutritional status - BIA } & \multirow[b]{2}{*}{$P$} \\
\hline & $\begin{array}{l}\text { Malnourished } \\
\quad(n=14)\end{array}$ & $\begin{array}{c}\text { Well } \\
\text { nourished } \\
(n=11)\end{array}$ & \\
\hline VET (kcal) & $2009 \pm 572$ & $2014 \pm 905$ & $0.986^{*}$ \\
\hline VET $(\mathrm{kcal} / \mathrm{kg})$ & $27.6 \pm 7.8$ & $24.8 \pm 9.1$ & $0.414^{*}$ \\
\hline Below the recommended - $\mathrm{n}(\%)$ & $6(42.9)$ & $6(54.5)$ & \\
\hline Recommended - n (\%) & $3(21.4)$ & $1(9.1)$ & \\
\hline Above recommended - n (\%) & $5(35.7)$ & $4(36.4)$ & \\
\hline $\mathrm{CHO}(\mathrm{g})$ & $289 \pm 97.5$ & $281 \pm 136$ & $0.860 *$ \\
\hline $\mathrm{CHO}(\%)$ & $57.0 \pm 7.7$ & $55.5 \pm 5.9$ & $0.591 *$ \\
\hline Below the recommended - $\mathrm{n}(\%)$ & $2(14.3)$ & $2(18.2)$ & \\
\hline Recommended - n (\%) & $8(57.1)$ & $5(45.5)$ & \\
\hline Above recommended - n (\%) & $4(28.6)$ & $4(36.4)$ & \\
\hline PTN $(g)$ & $80.2 \pm 24.0$ & $78.8 \pm 31.0$ & $0.896^{*}$ \\
\hline PTN $(\mathrm{g} / \mathrm{kg})$ & $1.10 \pm 0.31$ & $0.98 \pm 0.40$ & $0.430 *$ \\
\hline Below the recommended - $\mathrm{n}(\%)$ & $8(57.1)$ & $7(63.6)$ & \\
\hline Recommended - n (\%) & $2(14.3)$ & $0(0.0)$ & \\
\hline Above recommended - n (\%) & $4(28.6)$ & $4(36.4)$ & \\
\hline $\operatorname{LIP}(\mathrm{g})$ & $64.4 \pm 19.2$ & $65.8 \pm 32.5$ & $0.894 *$ \\
\hline LIP (\%) & $29.3 \pm 4.5$ & $29.2 \pm 4.4$ & $0.923 *$ \\
\hline Below the recommended - $\mathrm{n}(\%)$ & $0(0.0)$ & $0(0.0)$ & \\
\hline Recommended - n (\%) & $14(100)$ & $11(100)$ & \\
\hline Zinc (mg) & $9.4 \pm 3.1$ & $8.7 \pm 3.2$ & $0.560 *$ \\
\hline Below the recommended - $\mathrm{n}(\%)$ & $6(42.9)$ & $3(27.3)$ & \\
\hline Recommended - n (\%) & $8(57.1)$ & $8(72.7)$ & \\
\hline Iron $(\mathrm{mg})$ & $14.3 \pm 3.8$ & $14.9 \pm 9.0$ & $0.828 *$ \\
\hline Below the recommended - $\mathrm{n}(\%)$ & $0(0.0)$ & $0(0.0)$ & \\
\hline Recommended - n (\%) & $14(100)$ & $11(100)$ & \\
\hline Sodium $(\mathrm{mEq})$ & $99.5 \pm 52.9$ & $114 \pm 63.9$ & $0.530 *$ \\
\hline Below the recommended - $\mathrm{n}(\%)$ & $1(7.1)$ & $3(27.3)$ & \\
\hline Recommended - n (\%) & $3(21.4)$ & $0(0.0)$ & \\
\hline Above recommended - $\mathrm{n}(\%)$ & $10(71.4)$ & $8(72.7)$ & \\
\hline Potassium (mg) & $1966 \pm 648$ & $1896 \pm 965$ & $0.830 *$ \\
\hline Below the recommended - $\mathrm{n}(\%)$ & $14(100)$ & $11(100)$ & \\
\hline Recommended - n (\%) & $0(0.0)$ & $0(0.0)$ & \\
\hline Calcium (mg) & $557 \pm 189$ & $671 \pm 334$ & $0.330 *$ \\
\hline Below the recommended - $\mathrm{n}(\%)$ & $14(100)$ & $10(90.9)$ & \\
\hline Recommended - n (\%) & $0(0.0)$ & $1(9.1)$ & \\
\hline
\end{tabular}

for the malnourished (57.1\%) and well nourished (45.5\%); protein intake was lower than recommended in $57.1 \%$ of malnourished and $63.6 \%$ of well nourished; lipids intake was within the recommended to all patients, well nourished and malnourished (Table 4).

We observed that patients intake of macronutrients and micronutrients did not statically differed in weekdays and weekends $(P>0.05)$.

\section{DISCUSSION}

First, we must comment the limitations of this study. The sample consisted of cirrhotic outpatients of the Sistema Único de Saúde (SUS), of low socioeconomic status, this may have hindered their understanding for carrying out the three-day food record. The method used for the analysis of food consumption, three-days food record using scales, despite being considered a good instrument, is based on information from each weighed food and recorded by the patient or caregiver, this requires effort and collaboration will from them ${ }^{21)}$. It should also be noted the lack of studies related to this subject, especially with the use of 3 days food diaries with the scales use, which provides us with objective consumption data, which does not depend on the patient's memory, as the $24 \mathrm{~h}$ record, most commonly used. Besides, even being ambulatory patients, they could present some degree of encephalopathy and cognitive impairment that could have compromised the food intake registration. Another factor is the low number of Child-Pugh C patients, since they are outpatients, which ultimately leaves the sample inhomogeneous. This fact may jeopardize the results of the associations with the staging of the disease.

Regarding the studied group, it was observed that the most prevalent etiology of cirrhosis was the hepatitis $\mathrm{C}$ virus, this information meets the published data, which shows that the leading cause of cirrhosis in the Western world is infection with hepatitis $\mathrm{C}$, associated or not with alcohol abuse $\mathrm{e}^{(26,35)}$.

In the present study, we evaluated the nutritional status of the cirrhotic by different methods and it was observed that BMI diagnosed $64 \%$ of patients as overweight. This result is consistent with the study by Fernandes et al. ${ }^{(13)}$, which evaluated 129 outpatients with liver cirrhosis a hospital in Porto Alegre, Brazil, in which the IMC identified the prevalence of overweight in the population studied. As Gottschall et al. ${ }^{(17)}$, in a study of 34 patients with cirrhosis was the hepatitis $\mathrm{C}$ virus in outpatient treatment at the Gastroenterology Department of the Hospital de Clínicas de Porto Alegre (HCPA), RS, which found a prevalence of overweight in $62 \%$ of subjects. The UAC, HGS and PA by BIA were the methods that most diagnosed malnourished, and these data are in agreement with studies published in the literature ${ }^{(13,17,27)}$, as Fernandes et al. ${ }^{(13)}$ who found a prevalence of malnutrition ranging from $14 \%$ by CB to $69.3 \%$ by FAM, and Gottschall et al. ${ }^{(17)}$ showed a prevalence of $79.4 \%$ of malnourisheds by FAM.

To compare nutritional status with consumption, we chose just one nutritional assessment method. As there is not, to date, an evaluation method considered "gold standard", we performed an association of all methods used with Child-Pugh score for disease staging, given that the higher the Child -Pugh, the more severe is the disease and, therefore, worse the nutritional status. Thus, we observed a significantly statistical difference $(P<0.05)$ for phase angle by BIA and UAC. It was decided to choose the phase angle by BIA because a Brazilian study published previously ${ }^{(13)}$ showed that this was the only method of assessment that is 
associated with Child-Pugh score. In addition, the European Society for Clinical Nutrition and Metabolism (ESPEN), in its guideline, recommends BIA as a valid method to assess nutritional status in cirrhotic patients ${ }^{(30)}$. UAC was not used, despite having a statistically significant association, because it should not be used as a single parameter classification, but be used as a basis for obtaining the arm muscle circumference along with triceps skinfold ${ }^{(14)}$.

The average calorie intake, in the general sample, was $26.4 \pm 8.4 \mathrm{kcal} / \mathrm{kg}$, which showed an average within the recommended in the literature ${ }^{(6)}(25-30 \mathrm{kcal} / \mathrm{kg})$. However, it is noteworthy that $12(48 \%)$ patients had an intake below the recommended and 36\% above, this because it occurred wide variations in caloric intake, meaning that some patients had very high caloric intake and others, very low $(2012 \pm 720$ $\mathrm{kcal} / \mathrm{day})$. This fact characterizes what the literature have show, that chronic liver disease patients have a decreased food intake due to the disease's symptoms and dietary restrictions, which are often imposed therapeutically ${ }^{(8,23,31,33)}$. Low dietary intake has been considered as one of the major factors causing malnutrition ${ }^{(19)}$. The same goes for proteins, which general average consumption was within the recommended levels, however, $60 \%$ of patients had an intake below these values. Protein restriction is still widely used in clinical practice, even if the current recommendations are contrary ${ }^{(20)}$. This restriction has only been recommended in the treatment of encephalopathy, when it should be held for a period less than 24 hours. Moreover, cultural habits also contribute to a decreased protein intake. Inadequate calorie intake, especially protein, has significant deleterious effects on both nutritional status and clinical outcome ${ }^{(10,32)}$. In addition, sodium and liquid restriction is usual, which may contribute to the reduction of food intake ${ }^{(19)}$. In this context, we should consider that strict sodium restriction changes foods palatability, providing significant reduction in food intake and consequently worsening the nutritional status of these patients. However, in this study, sodium intake was above recommended levels in most patients, and only four of them consumed lower than recommended.

As for the minerals, the reduced zinc levels are quite common in cirrhotic patients, especially those with alcoholic origin. Zinc deficiency leads to hyperammonaemia, since it reduces the activity of the enzyme involved in the ammonia metabolism (ornithine transcarbamylase). Thus, zinc levels are reduced, especially in patients with encephalopathy grade I and II. Anorexia and altered taste are also consequences of zinc deficiency, which contributes to decreased intake and consequent malnutrition. As causes of this reduction, we have a poor dietary zinc intake, reduced intestinal absorption, reduced hepatointestinal extraction, portosystemic shunt, altered proteins and amino acids metabolism, as well as urinary zinc loss. In cirrhotic patients here studied, there was a decreased food intake in nine patients $(36 \%)$, and most of them $(64 \%)$ had a consumption within recommended. The opposite happened in the study of Gottschall et al. ${ }^{(17)}$, where zinc consumption was inadequate for most cirrhotic patients with hepatitis C. Oral supplementation of zinc produces a slight improvement in liver function, in hepatic protein synthesis and anorexia, in addition to the decrease in ammonia levels ${ }^{(6)}$.

The consumption of macronutrients and micronutrients did not vary according to the liver disease severity, according to the Child-Pugh score. The total calorie intake and protein of the Child-Pugh C patients was slightly lower than the others, but without significantly statistical difference. The consumption of micronutrients in Child-Pugh $\mathrm{C}$ patients had the same tendency to be smaller, but without statistical significance. We can attribute this result to the fact that there was only a few Child-Pugh C patients in the study. Only sodium had its consumption associated with the prognostic score of the Child-Pugh disease, that is, the higher the severity score, the lower the sodium consumption. This fact was already expected, since Child-Pugh C patients are the most serious and with more severe complications such as ascites, edema, all situations in which sodium restriction is recommended ${ }^{(10,32)}$.

When comparing the dietary intake and nutritional status by phase angle by BIA, it was observed that malnourished patients had a lower calorie intake than the well nourished, with no statistical significance.

Analyzing the dietary intake, according to different days of the week, we observed that, contrary to what we thought and what the literature shows ${ }^{(34)}$, the food consumption showed a certain pattern on three different days of the week, and did not vary even over the weekend. We can attribute this result to the fact that the studied patients were of low socioeconomic status, which hampers a variation in the daily diet.

\section{CONCLUSION}

Most patients were diagnosed as malnourished by the PA by BIA. The phase angle by BIA and UAC were the nutritional assessment tools that were associated with the Child-Pugh score.

The average dietary intake of cirrhotic patients was adequate for carbohydrates, proteins and lipids, zinc and iron. The potassium and calcium consumption was below the recommended daily and sodium was above.

Food intake did not vary according to the disease's stage, or according to the nutritional assessment by the phase angle by BIA. Only the sodium consumption was inversely associated with the disease's prognosis score.

It is suggested to carry out new studies to prove the present results, since we have a small number of patients, especially Child-Pugh C, which seem to be at higher risk for malnutrition.

\section{Authors' contributions}

Nunes FF: research implementation, data collection, statistical analysis, text editing. Bassani L: research implementation, data collection, text editing. Fernandes SA: research implementation, data collection. Deutrich ME: research implementation, data collection. Pivatto BC: data collection. Marroni CA: research implementation, text editing. 
Nunes FF, Bassani L, Fernandes SA, Deutrich ME, Pivatto BC, Marroni CA. Consumo alimentar de pacientes cirróticos, comparação com o estado nutricional e com o estadiamento da doença. Arq Gastroenterol. 2016,53(4):250-6.

RESUMO - Contexto - Os pacientes com doença hepática frequentemente apresentam desnutrição protéico-calórica. A avaliação da ingestão alimentar é de grande importância na investigação da relação do processo "saúde-doença". Objetivo - Avaliar o consumo alimentar de cirróticos através de registro alimentar de três dias, correlacionando-o com o estado nutricional do paciente e com o estadiamento da doença. Métodos - Avaliados pacientes cirróticos ambulatoriais da Santa Casa de Misericórdia de Porto Alegre, RS, Brasil. A avaliação nutricional foi realizada pela antropometria; força do aperto de mão não-dominante; espessura do músculo adutor do polegar; ângulo de fase pela bioimpedância elétrica; e Avaliação Subjetiva Global. Para análise do consumo alimentar utilizou-se o registro alimentar de 3 dias com balança para pesagem de todos os alimentos. Resultados - Avaliou-se 25 (68\%) pacientes, com predominância de cirrose pelo vírus da hepatite C. A circunferência do braço, a força do aperto de mão não-dominante e o ângulo de fase pela bioimpedância elétrica diagnosticaram $56 \%$ de desnutridos. O ângulo de fase pela bioimpedância elétrica e a circunferência do braço tiveram associação com o escore Child-Pugh $(P<0,05)$. O consumo médio de calorias, carboidratos, proteínas e lipídeos estavam dentro do recomendado. No entanto, o de sódio ficou acima das recomendações, $106 \pm 57,2 \mathrm{mEq}$, e associou-se inversamente com o escore Child-Pugh ( $r s=-0,410 ; P=0,042)$. Conclusão - Não houve diferença estatisticamente significativa entre os escores Child-Pugh e estado nutricional. Além disso, o consumo alimentar não variou conforme o estadiamento da doença, nem de acordo com a avaliação nutricional pelo ângulo de fase pela bioimpedância elétrica.

DESCRITORES - Cirrose hepática. Consumo alimentar. Avaliação nutricional.

\section{REFERENCES}

1. Alberino F, Gatta A, Amodio P, Merkel C, Dipascoli L, Boffo G, et al. Nutrition and survival in patients with liver cirrhosis. Nutrition. 2001;17:445-50.

2. Álvares-da-Silva MR, Silveira TR. O estudo da força do aperto de mão nãodominante em indivíduos sadios. Determinação dos valores de referência para o uso da dinamometria. GED Gastroenterol Endosc Dig. 1998; 17:203-6.

3. Anção MS, Cuppari L, Draibe AS, Sigulem D. Programa de apoio à nutrição-Nutwin, versão 1.5. São Paulo: Departamento de informática em saúde, SPDM, Unifesp/EPM, 2002. [Cd-Rom]

4. Barbosa-Silva MC, Barros AJ, Larsson E. Phase angle reference values for Brazilian population. Int J Body Compos Res. 2008;6:67-8.

5. Barbosa-Silva MC, Barros AJ, Post CL, Waitzberg DL, Heymsfield SB. Can bioelectrical impedance analysis identify malnutrition in preoperative nutrition assessment? Nutrition. 2003;19:422-6.

6. Bianchi G, Marzocchi R, Lorusso C, Ridolfi V, Marchesini G. Nutritional treatment of chronic liver failure. Hepatol Res. 2008;38(Suppl 1):93-101.

7. Blackburn GL, Thornton PA. Nutritional assessment of the hospitalized patients. Med Clin North Am. 1979;63:1103-15.

8. Campillo B, Richardet JP, Scherman E, Bories PN. Evaluation of nutritional practice in hospitalized cirrhotic patients: results of a prospective study. Nutrition. 2003;19:515-21.

9. Carvalho L, Parise ER. Evaluation of nutritional status of nonhospitalized patients with liver cirrhosis. Arq. Gastroenterol. 2006;43:269-74.

10. Cordoba J, Lopez-Hellin J, Planas M, Sabin P, Sanpedro F, Castro F, et al. Normal protein diet for episodic hepatic encephalopathy: results of a randomized study. J Hepatol. 2004;41:38-43.

11. Detsky AS, Baker JP, Mendelson RA, Wolman SL, Wesson DE, Jeejeebhoy $\mathrm{KN}$. Evaluating the accuracy of nutritional assessment techniques applied to hospitalized patients: methodology and comparison. JPEN J Parenter Enteral Nutr. 1984;8:153-9.

12. Duarte ACG. Avaliação nutricional: aspectos clínicos e laboratoriais. São Paulo: Atheneu; 2007. p.269-273.

13. Fernandes SA, Bassani L, Nunes FF, Aydos MEDe, Alves AV, Marroni CA. Nutritional assessment in patients with cirrhosis. Arq. Gastroenterol. 2012;49:19-27.

14. Figueiredo FA, Dickson ER, Pasha TM, Porayko MK, Therneau TM, Malinchoc $\mathrm{M}$, et al. Utility of standard nutritional parameters in detecting body cell mass depletion in patients with end-stage liver disease. Liver Transpl. 2000;6:575-81.

15. Fisberg RM, Martini LA, Slater B. Métodos de inquéritos alimentares. In: Fisberg RM, Slater B, Marchioni DML, Martini LA. Inquéritos alimentares: métodos e bases científicos. São Paulo: Manole; 2005. p.1-31.

16. Frisancho AR. Anthropometric standards for the assessment of growth and nutritional status. Ann Arbor, Michigan: University of Michigan Press; 1990.

17. Gottschall CBA, Álvares-da-Silva MR, Camargo ACR, Buertett RM, Silveira TR. Avaliação nutricional de pacientes com cirrose pelo vírus da hepatite C: a aplicação da calorimetria indireta. Arq Gastroenterol. 2004;41:220-4.
18. Gunsar F, Raimondo ML, Jones S, Terreni N, Wong C, Patch D, et al. Nutritional status and prognosis in cirrhotic patients. Aliment Pharmacol Ther. 2006;24:563-72.

19. Henkel AS, Buchman AL. Nutritional support in patients with chronic liver disease. Nat Clin Pract Gastroenterol Hepatol. 2006;3:202-9.

20. Heyman JK, Whitfield CJ, Brock KE, Mccaughan GW, Donaghy A. Dietary protein intakes in patients with hepatic encephalopathy and cirrhosis: current practice in NSW and ACT. Med J Aust. 2006;185:542-3.

21. Holanda L, Filho AAB. Métodos aplicados em inquéritos alimentares. Rev Paul Pediatria. 2006;24:62-70.

22. Huisman EJ, Trip EJ, Siersema PD, van Hoek B, van Erpecum KJ. Protein energy malnutrition predicts complications in liver cirrhosis. Eur J Gastroenterol Hepatol. 2011;23:982-9.

23. Kalaitzakis E, Simren M, Olsson R, Henfridsson P, Hugosson I, Bengtsson M, et al. Gastrointestinal symptoms in patients with liver cirrosis: association with nutritional status and healthrelated quality of life. Scand J Gastroenterol. 2006;41:1464-72.

24. Kondrup J. Nutrition in end stage liver disease. Best Pract Res Clin Gastroenterol. 2006;20:547-60.

25. Lameu EB, Gerude MF, Corrêa RC, Lima KA. Adductor policis muscle: a new anthropometric parameter. Rev Hosp Clin Fac Méd S Paulo. 2004;59:57-62.

26. McAvoy NC, Hayes PC. The cirrhosis epidemic in the UK: evaluating the causes in a European context. Expert Rev Gastroenterol Hepatol. 2007;1:41-5.

27. Nunes FF, Fernandes SA, Bertolini CM, Rabito EI, Gottschall CBA. Nutritional evaluation of cirrhotic patients: comparison between several methods. Scientia Medica. 2012,22:12-7.

28. Padovani RM, Amaya-Farfán J, Colugnati FAB, Domene SMA Dietary reference intakes: aplicabilidade das tabelas em estudos nutricionais. Rev. Nutr. 2006;19:741-60.

29. Parolin MB, Zaina FE, Lopes RW. Terapia nutricional no transplante hepático. Arq. Gastroenterol. 2002;39:114-22.

30. Plauth M, Cabre E, Riggio O, Assis-Camilo M, Pirlich M, Kondrup J, et al. ESPEN guidelines on enteral nutrition: liver disease. Clin Nutr. 2006;25:285-94.

31. Plauth M, Schutz ET. Cachexia in liver cirrhosis. Int J Cardiol. 2002;85:83-7.

32. Richardson RA, Davidson HI, Hinds A, Cowan S, Rae P, Garden JO. Influence of the metabolic sequelae of liver cirrhosis on nutritional intake. Am J Clin Nutr. 1999;69:33137.

33. Ritter L, Gazzola J. Avaliação nutricional no paciente cirrótico: uma abordagem objetiva, subjetiva ou multicompartimental? Arq Gastroenterol. 2006;43:66-70.

34. Sallum BB, Rossi L, Honsi CC. Análise comparative co consume alimentar habitual e dos finais de semana de pacientes de uma clínica de nutrição de São Paulo. Revista Brasileira de Obesidade, Nutrição e Emagrecimento. 2015;50:59-66.

35. Schuppan D, Afdhal NH. Liver Cirrhosis. Lancet. 2009;371:838-51.

36. World Health Organization. Obesity: Preventing and managing the global epidemic. Technical report series, n.894, 2000. 